\title{
Liter per Nanogram per Hour
}

National Cancer Institute

\section{Source}

National Cancer Institute. Liter per Nanogram per Hour. NCI Thesaurus. Code C85686.

Liters per nanogram per hour. 